\title{
Two reviews of full crown restorations
}

\begin{tabular}{|l|l|l|} 
Abstracted from & $\begin{array}{l}\text { Podhorsky A, Rehmann P, Wöstmann B. } \\
\text { Tooth preparation for full-coverage restorations-a } \\
\text { literature review. Clin Oral Investig 2015; 19: 959-968 } \\
\text { Mar 7. [Epub ahead of print] PubMed PMID: 25743567. }\end{array}$ & $\begin{array}{l}\text { Tiu J, Al-Amleh B, Waddell JN, Duncan WJ. } \\
\text { Clinical tooth preparations and associated measuring } \\
\text { methods: a systematic review. J Prosthet Dent 2015; 113: } \\
\text { 175-184. doi: 10.1016/j.prosdent.2014.09.007. Epub } \\
\text { 2014Nov 25. Review.PubMed PMID: 25449611. }\end{array}$ \\
\hline
\end{tabular}

\begin{tabular}{|c|c|c|}
\hline Question: & $\begin{array}{l}\text { What effects do biological } \\
\text { parameters, preparation geometry } \\
\text { and technical factors have in } \\
\text { the clinical success of full crown } \\
\text { restorations? }\end{array}$ & $\begin{array}{l}\text { What are the clinically achievable } \\
\text { geometric parameters of a tooth } \\
\text { prepared for a crown? (ie total occlusal } \\
\text { convergence (TOC) angle, margin } \\
\text { design, prepared abutment height, } \\
\text { etc) What methods are currently used } \\
\text { to measure these parameters? }\end{array}$ \\
\hline Data sources & $\begin{array}{l}\text { Medline, DIMDI (German Institute for Medical } \\
\text { Documentation and Information) and Cochrane library } \\
\text { with an additional hand searching of journals in German } \\
\text { language not listed in Medline. }\end{array}$ & Scopus, Pubmed and ScienceDirect. \\
\hline Study selection & $\begin{array}{l}\text { Clinical, in-vitro and animal studies specific to indirect } \\
\text { full coverage restorations were included. Case reports } \\
\text { were excluded. There was no language restriction. Three } \\
\text { reviewers screened titles, with disagreements being } \\
\text { resolved through discussion. }\end{array}$ & $\begin{array}{l}\text { Only English language clinical studies limited to } \\
\text { teeth prepared for single indirect full coverage crown } \\
\text { restorations were included. Reviews, case reports, } \\
\text { letters to the editor, animal studies, or studies relating } \\
\text { to onlays/inlays, partial fixed dental prostheses or } \\
\text { implants were excluded. Two reviewers screened titles } \\
\text { independently. Disagreements between reviewers were } \\
\text { resolved through discussion with a third reviewer. }\end{array}$ \\
\hline $\begin{array}{l}\text { Data extraction } \\
\text { and synthesis }\end{array}$ & $\begin{array}{l}\text { A narrative summary of the biological parameters } \\
\text { was presented. }\end{array}$ & $\begin{array}{l}\text { This included: authors and year of the study; whether } \\
\text { the tooth was prepared intraorally or extraorally; the } \\
\text { number of specimens in the study; tooth type; the } \\
\text { buccolingual and mesiodistal TOC angle; abutment } \\
\text { height and margin design (with standard deviation); the } \\
\text { operator who performed the crown preparation; and the } \\
\text { methods used to measure the values collected. }\end{array}$ \\
\hline Results & $\begin{array}{l}\text { One hundred and seventeen met this review's inclusion } \\
\text { criteria ( } 11 \text { reviews, } 23 \text { clinical studies, } 1 \text { animal } \\
\text { investigation and } 82 \text { in vitro experiments.) Only the } \\
\text { following statement is supported by moderate quality } \\
\text { evidence: supra-gingival margins have no detrimental } \\
\text { effect on periodontal tissue while sub-gingival margins } \\
\text { cause periodontal inflammation. }\end{array}$ & $\begin{array}{l}\text { Twenty-three articles met this review's inclusion } \\
\text { criteria. Twenty articles reported TOC angles ( } n=1,463 \\
\text { specimens), buccolingual dimension (range } 7.4-35.7 \\
\text { degrees) and mesiodistal (range } 7.1-37.2 \text { degrees). Four } \\
\text { articles reported margin width ( } n=3,763 \text {, ranging from } \\
0.45-1.00 \mathrm{~mm} \text { ) and angle ( } n=3,680 \text {, ranging from } 33-110 \\
\text { degrees depending if finish margin was a chamfer, bevel, } \\
\text { feather, butt or chamfer) and three articles reported } \\
\text { the height of the prepared abutment ( } n=153 \text {, ranging } \\
\text { from 2.3-6.9 mm). Values varied considerably based on } \\
\text { tooth type, location in the mouth, type of crown (metal, } \\
\text { metal-ceramic or all-ceramic), as well as the definition and } \\
\text { various methods used to measure them. }\end{array}$ \\
\hline Conclusions & $\begin{array}{l}\text { With the exception of the location of crown margins, } \\
\text { low to very low quality evidence currently exists on the } \\
\text { effects that biological parameters, preparation geometry } \\
\text { and technical factors have on clinical outcomes. }\end{array}$ & $\begin{array}{l}\text { The current achievable crown parameters reported in } \\
\text { the literature generally fall short of those conventionally } \\
\text { recommended. Standardised and objective methods } \\
\text { of analysing preparation geometry are needed. Also, } \\
\text { clinical trials are needed to determine the implications of } \\
\text { these geometric values on clinical success. }\end{array}$ \\
\hline
\end{tabular}




\section{Commentary}

The full crown restoration is recommended to improve the longevity of teeth significantly broken down from underlying decay or trauma. ${ }^{1}$ The standard geometric and technical criteria of the prepared tooth have not changed much in over fifty years. ${ }^{2,3}$ Recent reviews by Tiu et al. and Podhorsky et al. have summarised the literature with the aim of better understanding the achievability of the recommended standards in clinical practice and the effects they may have on the treatment prognosis. ${ }^{4,5}$

Tiu et al. limited their question to the geometric design of the prepared tooth, with the vast majority of included studies reporting on the TOC. Interestingly, they found the TOC values typically achieved clinically far exceed historically recommended angles quoted in standard textbooks. ${ }^{1}$

Acute TOC angles are shown to optimise retention and resistance of the final restoration and are believed to minimise the mechanical stress on the luting cement. But these recommendations were made at a time when crowns were often luted with zinc-phosphate cement. With the significant advancements in dental materials over the last half century, today's crowns are often cemented with materials (eg resin and glass ionomer) which have higher compressive and tensile strengths, as well as tooth bonding properties. $^{6}$

Podhorsky et al. aimed to evaluate if the conventional wisdom of tooth preparation was evidence based. The review analysed how various geometric, technical and biologic factors affect clinical outcomes, eg preparation geometry, preparation depth into dentin, location of a preparation's margin to periodontium, grit of diamond bur and the subsequent heat generated during tooth preparation and dental crown design. Nineteen clinical recommendations that the authors made were supported with low to very low quality evidence. They were only able to find moderate clinical evidence recommending that crown margins be placed supra-gingivally.

Both reviews failed to describe clear methodologies and validated standards of how they evaluated (i) the quality and (ii) the risk of bias of the included studies. For example, neither review presented detailed descriptions nor standardised critical appraisal processes for the individual studies they included. Tiu et al. did not describe how a lack of evaluator blinding in each study may have contributed to expectation bias. Furthermore, Podhorsky et al. did not assess how the potential bias from likely censored data (patients lost to follow-up) in each study may have threatened the validity of their recommendations.

Conventional wisdom behind the recommended parameters of tooth preparation and crown design seeks to balance two objectives: long term survival of restorations relative to risk of harm to the endodontic or periodontal complex. Both reviews, despite the limitations I have noted, did acknowledge the lack of good quality clinical evidence connecting the former to the latter.

Ben Balevi

University of British Columbia, Vancouver, Canada

1. Shillingburg HT, Sather DA, Sonte SE. Fundamentals of fixed prosthodontics 4 th ed Chicago: Quintessence Publishing Co In 2012.

2. Goodacre Cl, Campagni WV, Aquilino SA. Tooth preparations for complete crowns: an art form based on scientific principles. J Prosthet Dent 2001; 85: 363-367.

3. Seymour KG. Samarawickrama DY, Lynch EJ. Metal ceramic crowns--a review of tooth preparation. Eur J Prosthodont Restor Dent 1999; 7: 79-84.

4. Podhorsky A, Rehmann P, Wöstmann B.Tooth preparation for full-coverage restorations-a literature review. Clin Oral Invest March 2015 DOI 10.1007/s00784015-1439-y

5. Tiu et al, Clinical tooth preparation and association measuring methods: A systematic review, J Prosthet Dent 2015; 113:113-184

6. Donald Lee Wis Encyclopedic Handbook of Biomaterials and Bioengineering: v. 1-2. Applications - New York CRC Press 1995

Evidence-Based Dentistry (2015) 16, 35-36. doi:10.1038/sj.ebd.6401107 